\title{
Erratum to: Climatic drivers of potential hazards in Mediterranean coasts
}

\author{
Agustín Sánchez-Arcilla - Cesar Mösso - Joan Pau Sierra - Marc Mestres • \\ Ali Harzallah $\cdot$ Mohamed Senouci $\cdot$ Mohamed El Raey $\cdot$ Hesham El-Askary
}

Published online: 18 February 2011

(c) Springer-Verlag 2011

\section{Erratum to: Reg Environ Change \\ DOI 10.1007/s10113-010-0193-6}

Unfortunately Dr. Hesham El-Askary was left out in the original publication of this article. He has actively participated with Professor Dr. Mohamed El-Raey in the research work. His name is now included in the author group and the affiliation is as follows:

The online version of the original article can be found under doi:10.1007/s10113-010-0193-6.

A. Sánchez-Arcilla $(\bowtie) \cdot$ C. Mösso · J. P. Sierra · M. Mestres Laboratori d'Enginyeria Marítima,

Universitat Politècnica de Catalunya,

Jordi Girona 1-3, Edifici D1 Campus Nord,

08034 Barcelona, Spain

e-mail: agustin.arcilla@upc.edu

A. Sánchez-Arcilla · C. Mösso · J. P. Sierra · M. Mestres Centre Internacional d'Investigació dels Recursos Costaners, Jordi Girona 1-3, Edifici D1 Campus Nord,

08034 Barcelona, Spain

\section{A. Harzallah}

Institut National des Sciences et Technologies de la Mer,

28, rue du 2 mars 1934, 2025 Salammbo, Tunisia

e-mail: ali.harzallah@instm.rnrt.tn

\section{Senouci}

Membre du Groupe Intergouvernemental sur l'Evolution du

Climat (IPCC), Association de Recherche Climat

Environnement, ARCE, BP 4250, Ibn Rochd,

31037 Oran, Algeria

e-mail: msenouci@wissal.dz
Hesham El-Askary, Ph.D.

School of Earth and Environmental Sciences, Schmid College of Science, Chapman University, California.

Department of Environmental Sciences, Faculty of Science, Alexandria University, Egypt.

\author{
M. El Raey \\ Alexandria University, Arab Academy of Science and \\ Technology and Maritime Transport, \\ El-Guish Road, El-Shatby, Alexandria 21526, Egypt \\ e-mail: melraey@gmail.com \\ H. El-Askary \\ School of Earth and Environmental Sciences, \\ Schmid College of Science, Chapman University, \\ Orange, CA, USA \\ H. El-Askary \\ Department of Environmental Sciences, Faculty of Science, \\ Alexandria University, Alexandria, Egypt
}

